\title{
Correction to: Dialectical behaviour therapy for treating adults and adolescents with emotional and behavioural dysregulation: study protocol of a coordinated implementation in a publicly funded health service
}

Daniel Flynn ${ }^{1}$, Mary Kells ${ }^{2}$, Mary Joyce ${ }^{2 *}$, Catalina Suarez ${ }^{2}$ and Conall Gillespie ${ }^{2}$

\section{Correction}

Upon publication of the original article [1] it was highlighted by the authors that there was just one error in the manuscript in the 'Sample size' subsection of the Methods/Design. The current text reads:

"It is anticipated that there will be a total of 442 participants across 16 sites in this research study over a four year period. Of the 312 , it is estimated that 120 will be adults with a primary diagnosis of BPD attending Adult Mental Health Services across eight study sites......."

The correct text should have "312" replaced with "442" so that it reads:

"It is anticipated that there will be a total of 442 participants across 16 sites in this research study over a four year period. Of the 442, it is estimated that 120 will be adults with a primary diagnosis of BPD attending Adult Mental Health Services across eight study sites......." This has since been formally noted in this Correction article.

\section{Author details}

${ }^{1}$ Cork Mental Health Service, Cork Kerry Community Healthcare, Health Service Executive, St Finbarr's Hospital, Cork, Ireland. ${ }^{2}$ National Suicide Research Foundation, Western Gateway Building, University College Cork, Cork, Ireland.
Published online: 07 May 2018

\section{Reference}

1. Flynn D, Kells M, Joyce M, Suarez C, Gillespie C. Dialectical behaviour therapy for treating adults and adolescents with emotional and behavioural dysregulation: study protocol of a coordinated implementation in a publicly funded health service. BMC psychiatry. 2018;18(1):51.

* Correspondence: maryc.joyce@hse.ie; marychjoyce@gmail.com

${ }^{2}$ National Suicide Research Foundation, Western Gateway Building, University College Cork, Cork, Ireland

Full list of author information is available at the end of the article

(c) The Author(s). 2018 Open Access This article is distributed under the terms of the Creative Commons Attribution 4.0 International License (http://creativecommons.org/licenses/by/4.0/), which permits unrestricted use, distribution, and reproduction in any medium, provided you give appropriate credit to the original author(s) and the source, provide a link to the Creative Commons license, and indicate if changes were made. The Creative Commons Public Domain Dedication waiver (http://creativecommons.org/publicdomain/zero/1.0/) applies to the data made available in this article, unless otherwise stated. 